\title{
OSGOOD SCHLATTER'S DISEASE IN YOUNG BASKETBALL PLAYERS
}

\author{
Jakovljević Aleksandar ${ }^{1}$, Grubor Predrag ${ }^{2}$, Simović Slobodan ${ }^{3}$, \\ Bijelić Snežana $^{3}$, Maran Milorad ${ }^{2} \&$ Kalacun Dario ${ }^{2}$ \\ ${ }^{1}$ Faculty of Medicine, Banja Luka, Bosnia \& Herzegovina \\ ${ }^{2}$ Clinic of Traumatology, Banja Luka, Bosnia \& Herzegovina \\ ${ }^{3}$ Faculty of Physical Education and Sport, Banja Luka, Bosnia \& Herzegovina
}

DOI: $10.5550 /$ sgia.1002074

ORIGINAL SCIENTIFIC PAPER

\section{SUMMARY}

In this work is presented the experience with Osgood Schlatters disease in young male basketball players. From one overall number of 257 young male basketball players with ages between 10 and 16 years is found that 23 or $8.9 \%$ had Osgood Schlatters disease. In control group of 250 young males (10-16 years) without sport activities is found $4 \%$ of Osgood Schlatters disease.

All patients were treated with rest of training and sports activities and after that with physioterapy. After 6 months everybody were allowed to have a full practice without clinical and radiological signs of disease.

Stronger physical activities in an early adolescent's period are one of main factors of appearing of Osgood Schlatters disease.

Key words: Osgood Schlater disease, basketball players, practice.

\section{INTRODUCTION}

Disease Osgood-Schlatter represents apophysitis of proximal corner of a shinbone (lat. Tibia) or avascular necrosis, which occurs in a time of adolescence, respectively in a time of pronounced growth (Picture 1). It is characterized with appearance of pain inside of tibial protuberance (lat. Tuborerositas tibiae) and probably represents inflammation of the glass of tendon and belonging cartilage plate growth tibia protuberance, and it is caused by physical activity, regarding traction. The magnetic resonance studies showed that in most cases, it is tendinitis of the glass of tendon, and in fewer cases, it comes to fragmentation of the bony part of the attachment of ligaments. It is observed that it frequently appears joined with "patella alta" syndrome. First time this illness is described in 1903 separately by American surgeon Robert Osgood and Swiss surgeon Carl Schlatter, and by them, it got a name. (Nowinski \& Mehlman, 1998)

\section{PICTURE 1}

Schematic view of the place appearing an OS illness

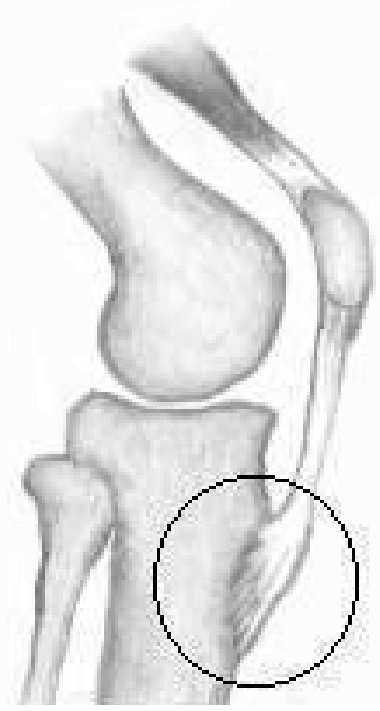


Usually it appears at the age of 10 to 15 years, and etiologic factors can be hormonal, mechanical, inflammatory, and hereditary, mainly in children who deal with sports $20 \%$ in a difference with others who do not deal with sports where frequency is $4 \%$. At boys, it occurs mainly in a period from 14 to 15 years, and at girls, it occurs earlier from 10 to 11 years. (Kujala, Kvist \& Heinonen, 1985)

Both knees are affected in nearly $25 \%$ of the cases. (Gholve, Scher, Khakharia, Widmann \& Green, 2007)

\section{PICTURE 2}

$X$-ray characteristic of the OS disease

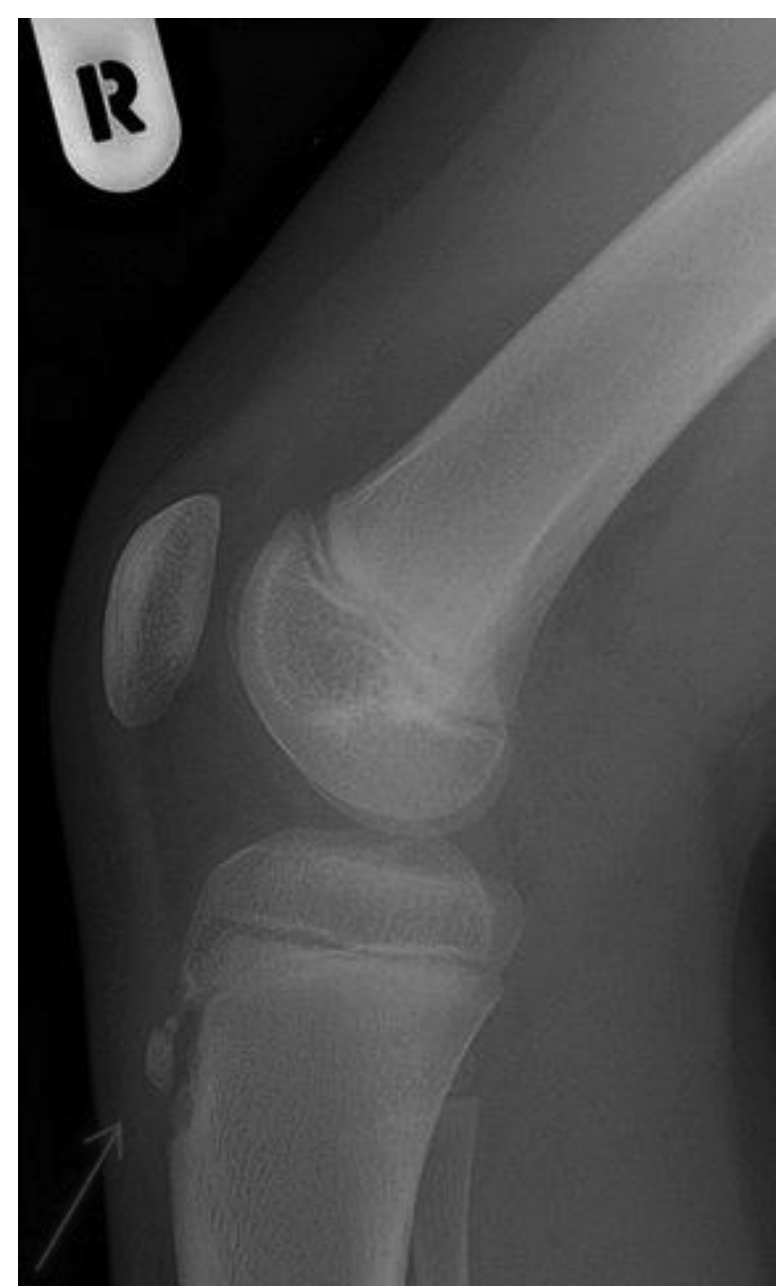

Detailed and correct anamnesis is very important (living conditions, diseases before, family anamnesis, does patient play sports and which, etc.). Next step is approaching to clinical examination. At first, doctor should exclude a possibility of existence of any other injury and/or disease in side of proximal cor- ner of a shinbone and knee. Characteristic sign is a painful sensitive bulge on a top side of a shinbone. (Picture 2) It is necessary to test does the pain increase during straining for headed muscle of upper leg or during jumping only on a leg on which is a painful bulge. If stated tests are positive, there is a big possibility that is an Osgood - Schalatter disease.

Of imaging (RTG) techniques, mainly, it is used native radiography, and with a cause to reject a possibility of existence of the bony tumors and fractures of a bone.

People who have an Osgood-Schlatter disease, they have a characteristic profile $\mathrm{X}$-ray image of a knee. (Picture 3) On it is seeable a bulge of attachment of tendon glass on shinbone, with irregular fragmented bone core (fragmented ossification), and swelling of the soft tissues. In some cases, ultrasound scan can be done, but it cannot replace X-ray images, even it gives better information about look of the tendon glass and its attachment. A magnetic resonance (MR) and a computed tomography (CT) are rarely used for diagnose of an Osgood-Schlatter disease. (Yashar, Loder \& Hensinger, 1995)

\section{PICTURE 3}

\section{A place of the most intensive}

pain in the side of a tibia bulge

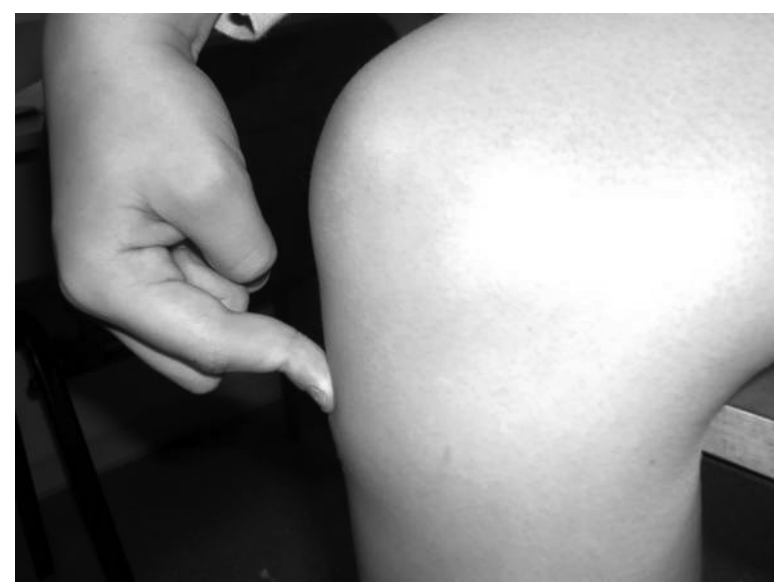

When establishing diagnose it is important to introduce a patient about natural course and prognosis of Osgood-Schlatter disease.

In curing process are used medications against pain, relief by splints and orthotics, and doing any sports activity is not recommended. (Cassas \& Cassettari-Wayhs, 2006) 
Despite applied therapeutic measures, symptoms (pain) could last for a different period of time, and as a rule, they totally disappear by end of a bone growth.

At the smaller number of patients (to 5.0 $\%$, complaints persist also after a bone growth and after a bone maturity. (Engel \& Windhager, 1987)

With those patients, there is a free bone fragment, or inside of a patellar tendon or inside insertions to the bone, and that fragment causes strong pain. At that time, it is identified surgeon treatment, what fallows, removing of that free fragment. (Strickland, Coleman, Brunswic \& Kocken, 2009; Canale \& Beaty, 2008)

The purpose of a work was to establish an incidence of causing an Osgood-Schlatter disease at adolescents basketball players in organized sport club and compare to an incidence of Osgood-Schlatter disease at adolescents who are not involved in organized sport clubs.

\section{METHODS}

In this work is tracked a group of young male basketball players from organized sport club in a period from January 2008 to June 2009 (in a further text group 1) and control male group, the same age, who were not involved in any sports activities.

In a group of young basketball players were tracked 257 boys, average age from 12.8 \pm 3.2 years, and in a control group there were 250 boys, average age from $13.1 \pm 3.1$ years.

Average body height of examinees in a group 1 was $162 \pm 40 \mathrm{~cm}$, and in a second group average height was $155 \pm 45 \mathrm{~cm}$.

Average body weight at subjects in the first group was $58 \pm 25 \mathrm{~kg}$, and in the second group average weight was $56 \mathrm{~kg} \pm 25 \mathrm{~kg}$.

Duration of basketball practice in the first group was $3.2 \pm 1$ year.

Average number of practices (with played games) in the first group, in a summertime period, was $8 \pm 2$ on a hard pad (asphalt) and $6 \pm 2$ in a winter period on parquet.

With all subjects, in both groups the anamnesis and clinic orthopedic examination was done, the positive findings (pain after moving, limited moving and pain caused by a pressure on a tibia bulge), were transferred to a radiotherapy (RTG images in a standard projections).

With setting a diagnose to all patients from this group, it is suggested stillness for six weeks with spear of practice and all other sport activities, even riding a bicycle. Two patients from the first group were suggested wearing an orthotics for knee.

After a first phase of stillness, which lasted from six weeks to three months, patients were indicated to a physical therapy lasting from fourteen to forty-two days.

Specific way of practice was beginning from six weeks to six months after finding this disease.

Results of the research were processed using methods of descriptive statistics. During the processing measures of central tendency of obtained data and arithmetic environment with expression of result in percentages were used.

\section{RESULTS}

In a group of boys who are dealing with sports activity (basketball), from total number of 257 we had 23 or $8.9 \%$ boys who had Osgood-Schlatter disease. In a control group from total of 250,10 boys $(4.0 \%)$ had Osgood-Schlatter disease. (Table 1 and Diagram 1)

TABLE 1.

Total number of $O S$ disease

compared to a number of examinees

\begin{tabular}{llll}
\hline & 1 & 2 & $\%$ \\
\hline Group 1 & 257 & 23 & 8.9 \\
\hline Group 2 & 250 & 10 & 4.0 \\
\hline
\end{tabular}

Legend: Group 1 - boys who are delaing with sports activity (basketball), Group 2 control group, $\mathbf{1}$ - total number of boys, 2 - boys who had Osgood-Schlatter disease.

Average age in a group 1 was 13.2 years, and in a control group 12.9 years. 
DIAGRAM 1.

Total number of $O S$ disease

compared to a number of examinees

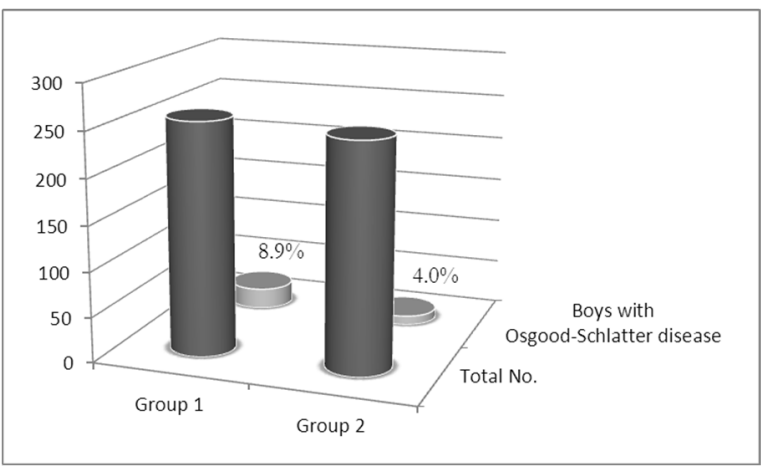

Mutual, Osgood-Schlatter disease appeared in the first group with 7 boys $(30.4 \%)$ and in a control group with 2 boys $(20.0 \%)$. (Table 2 and Diagram 2)

TABLE 2.

\section{Mutual appearance of $O S$ disease}

\begin{tabular}{llcc}
\hline & 1 & 2 & $\%$ \\
\hline Group 1 & 23 & 7 & 30.7 \\
\hline Group 2 & 10 & 2 & 20.0 \\
\hline
\end{tabular}

Legend: Group 1 - boys who are delaing with sports activity (basketball), Group 2 control group, 1 - boys who had OsgoodSchlatter disease, $\mathbf{2}$ - boys who had mutual appearance.

\section{DIAGRAM 2.}

\section{Mutual appearance of $O S$ illness}

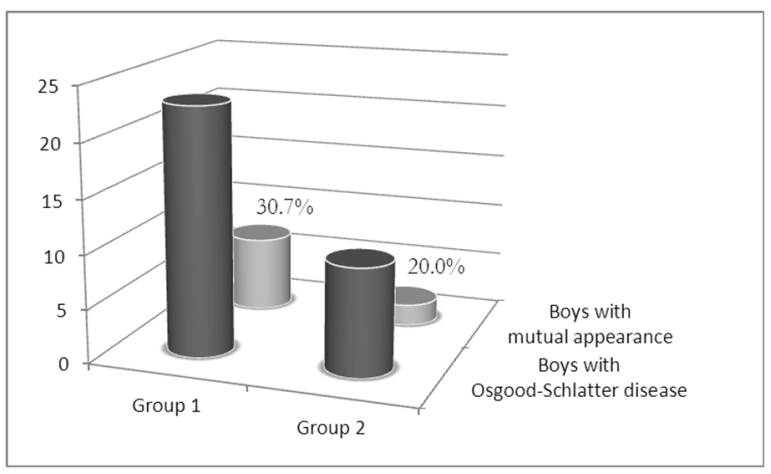

A way of curing was identical in both groups (stillness, analgesics, physical therapy).

Return to specific sport practice was allowed when there was no subjective feeling of pain and when all moves in a knee were painless.
A fully return to specific practice for six patients $(26.0 \%)$ was after six weeks, for ten patients $(43.0 \%)$ the return was possible after three months, yet for four patients (18.0\%) sports activities were enabled after four months. For three patients $(13.0 \%)$ the return to sports activities was possible after six months. (Table 3 and Diagram 3)

In both groups with an Osgood-Schlatter disease, a longest period of recovery was equal.

In a control group the return to school physical activity and to action of riding a bicycle was allowed after approximately three months.

TABLE 3.

Period of inability for doing sport activity - Group 1

\begin{tabular}{ccccc}
\hline & 1 & 2 & 3 & 4 \\
\hline Group 1 & $26.0 \%$ & $43.0 \%$ & $18.0 \%$ & $13.0 \%$ \\
\hline
\end{tabular}

Legend: $\mathbf{1}$ - a fully return to specific practice after six weeks, $\mathbf{2}-$ a fully return to specific practice after three months, $\mathbf{3}$ - a fully return to specific practice after four months, $\mathbf{2}-$ a fully return to specific practice after six months.

\section{DIAGRAM 3.}

Period of inability for doing sport activity - Group 1

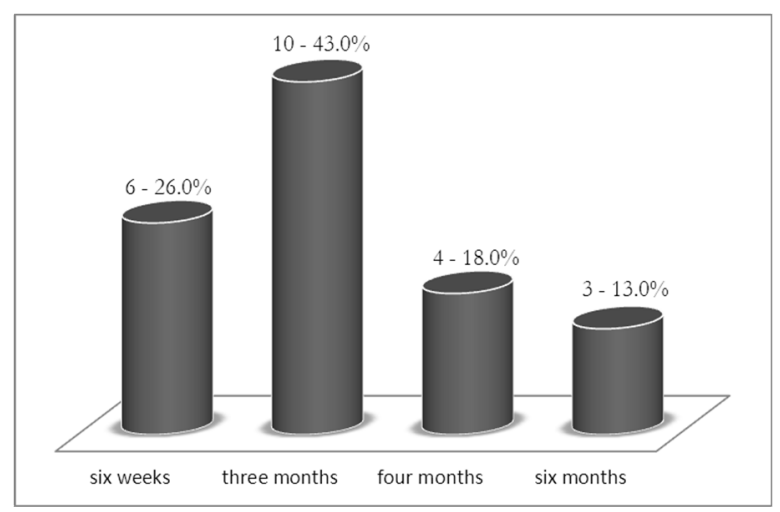

\section{DISCUSSION}

Sport has an important role in every area of human life. Physical activity influences positively on a healthy way of life, improvement of a health, and on quality of a life. One of main factors for healthy life is regular physical activity. It is impossible to count all positive aspects of physical activity, but without a doubt, some of them are: improvement of a 
health and quality of life, long lasting life and less risk for certain diseases, like hart and blood drain diseases, diabetes, malignant diseases, etc.

Beside all positive features of sports, regarding, certain sports activity, especially if they are done not respecting the age and gender of sportsman, could lead to appearance of certain diseases. One of them, which can appear because of hard sports activities, is sourly apofizitis of tibia bulge (Osgood-Schlatter).

Repeated and hard straining of patellar tendon on attachment on tibia bulge is a cause of mechanical trauma, which causes a change of phatoanatomic shape of tibia bulge that in a certain moment can transform in "inflammable" - non infected faze when pain appears.

One of the factors that enhance the appearance of this disease surly is an inadequate practice of young sportsman, which is consisting of greater and frequent practice with intensity that is not justified with biomechanical characteristics of bones-joint system in children and adolescents.

Frequency of Osgood-Schlatter disease at young sportsman (basketball players) in our work is $8.9 \%$ which is a little bit less from Finland author studies who found that $13.0 \%$ of Finland teenagers have a sings of this disease (Visuri et al, 2007) (Visuri, Pihlajamäki, Mattila, \& Kiuru, 2007), yet Brazilian authors showed prevalence of this disease in the same age group of Brazilian children from 9.8\%. (Gildasio, Gomes dos Santos \& Guerra, 2010)

However, beside a simple and easy discovery of this disease, at the biggest number of patients it occurs very late, almost in a phase of fragmentation - dividing of a tibia bulge when is required a long period of healing.

Reasons for late reporting of patients to a doctor are multiple, and the most common are that adolescents do not report pain that occurs from time to time because they can tolerate it very good, or because of a fear from going to a doctor, or a fear of a grant from practice. Mainly patients are reporting when parents notice that they have difficulties to walk, often they grab themselves for a knee, they complain about pain in an upper leg and similar. Than after determination of existence of this disease children and adolescents have difficulties to accept a way of healing which strongly restricts any harder physical activities like physical education, practice, riding a bicycle, and similar, and the some number of patients, hiding, do some stated physical activities and they prolong a return to physical activities to themselves.

Negligence of symptoms of this disease with inadequate healing and sooner return to a leg working process, could lead to impossibility of returning to a specific sport practice at all.

Reinforced physical effort of children and adolescents are not excluded cause of formation of this disease, which is proven in this work, where we showed that at children and adolescents who are not exposed to reinforced physical effort also comes to appearing of this disease, but in less percentage.

Prevention of Osgood-Schlatter disease includes exclusion of activity which leads to it. It is known that chronicle, repeated stress on a tendon of patella and its attachment on a tibia bulge cause this disease. Possible ways of prevention includes, beside else, adequate period of worm-up before competition activity or practice, which has for a cause a preparation of muscles and tendons for activity and increases their flexibility and resistance on well programed sports activity adjusted to a biochemical abilities of competitor, strengthening the quadriceps which leads to reducing a stress of patella tendon, and at the end establishment of a balance between the power of the front muscle (m. quadriceps) and rare (mm. hamstrings) group of upper leg is a very important for preventing reinforced stress of patellar tendon.

\section{CONCLUSION}

Reinforced sport activities in adolescent period are one of reasons for frequent appearance of apofizitis of tibia bulge, known under a Latin name Osgood-Schlatter disease. Inadequate legwork process by intensity and frequency surly plays a big role in a formation of this disease.

Knowing anatomic and biomechanical details of knee of the sportsman, which are in a phase of fast biological growth (adolescence) 
and with a right programming and periodization of practice, and all with an individual biological maturity of sportsman and his physical fitness, Osgood-Schlatter disease is possible to prevent.

\section{REFERENCE:}

Canale, S.T., Beaty, J.H. (2008). Campbell's Operative Orthopedics. 11th edition. Philadelphia: Mosby.

Cassas, K.J. \& Cassettari-Wayhs, A. (2006). Childhood and adolescent sports-related overuse injuries. American Family Physician 73(6), pp. 1014-1022.

Engel, A. \& Windhager, R. (1987). Importance of the ossicle and therapy of OsgoodSchlatter disease. [Der Stellenwert des Ossikels und der Therapie bei M. OsgoodSchlatter. In German.]. Sportverletz Sportschaden 1(2), pp. 100-108.

Gildasio, L.L., Gomes dos Santos \& C., Guerra, R.O. (2010). Prevalence and Associated Factors of Osgood-Schlatter Syndrome of Brazilian Adolescents in a PopulationBased Sample. American Journal of Sports Medicine, pp. 836-841.

Gholve, P.A., Scher, D.M., Khakharia, S., Widmann, R.F. \& Green, DW. (2007). Os- good Schlatter syndrome. Current Opinion in Pediatrics 19(1), pp. 44-50.

Kujala, U.M., Kvist, M. \& Heinonen, O. (1985). Osgood-Schlatter's disease in adolescent athletes - Retrospective study of incidence and duration. American Journal of Sports Medicine 13(4), pp. 236-241.

Nowinski, R.J. \& Mehlman, C.T. (1998). Hyphenated history Osgood-Schlatter disease. American Orthopedic 27(8), pp. 584-585.

Pećina, M., Bojanić, I. \& Hašpl, M. (2001). Stress syndrome in the knee. [Sindromi prenaprezanja u području koljena. In Croat.]. Arh. hig. rada toksikol., 52, pp. 429-439.

Strickland, J., Coleman, N., Brunswic, M. \& Kocken, R. (2008). Osgood-Schlatter's Disease: An Active Approach Using Massage and Stretching. European Congress of Sports Science Conference, appendix 1, pp. 78-82.

Visuri, T., Pihlajamäki, H.K., Mattila, V.M. \& Kiuru, M. (2007). Elongated patellae at the final stage of Osgood-Schlatter disease, a radiographic study. Knee Journal 14(3), pp 198-203.

Yashar, A., Loder, R.T. \& Hensinger, R.N. (1995). Determination of skeletal age in children with Osgood-Schlatter disease by using radiographs of the knee. Journal Pediatric Orthopedic, 15(3), pp. 298-301.

Received: November, $21^{\text {st }} 2010$ Accepted: December, $23^{\text {rd }} 2010$ Save Markalja 14 Correspodence to: Aleksandar Jakovljević, PhD Medicinski fakultete

78000 Banja Luka Bosnia and Herzegovina Phone: +387 65522213 E-mail: jakab@teol.net 


\title{
OSGOOD SCHLATTEROVO OBOLJENJE KOD MLADIH KOŠARKAŠA
}

\author{
Jakovljević Aleksandar ${ }^{1}$, Grubor Predrag ${ }^{2}$, Simović Slobodan $^{3}$, \\ Bijelić Snežana $^{3}$, Maran Milorad ${ }^{2} \&$ Kalacun Dario ${ }^{2}$ \\ ${ }^{1}$ Medicinski fakultet, Banja Luka, Bosna i Hercegovina \\ ${ }^{2}$ Klinika za traumatologiju, Banja Luka, Bosna i Hercegovina \\ ${ }^{3}$ Fakultet fizičkog vaspitanja i sporta, Banja Luka, Bosna i Hercegovina
}

Veliki broj djece i adolescenata uključen je $\mathrm{u}$ organizovane sportske aktivnosti te je broj pojave oboljenja tzv. sindroma prenaprezanja (engl. Overuse syndrom) sve veći. Sindromi prenaprezanja jesu oštećenja tetiva ili njihovih pripoja za kost do kojih dolazi zbrajanjem mnogih tzv. mikrotrauma. Sindromi prenaprezanja javljaju se i kod odraslih sportista i rekreativaca, ali imaju drugačije osobine. Djeca i adolescenti nisu samo "mali ljudi" jer se djeca u fazi ubrzanog rasta razlikuju od odraslih prema strukturama koje omogućavaju rast i razvoj, a to su ploče rasta, epifize i apofize i na tim osjetljivim hrskavičavim strukturama najčešće se pojavljuju sindromi prenaprezanja. Sposobnost djece da podnose dugotrajna opterećenja manja je nego kod odraslih. Kod djece za razliku od odraslih postoji na hvatištu tetive hrskavica koja je najčešće zahvaćena, pa govorimo o apofizitisu koji je jedna od najčešćih formi sindroma prenaprezanja kod djece sportista.

Ovo oboljenje ili sindrom može se naći i pod imenom juvenilne osteohondroze ili juvenilne osteonekroze, ali je suština poremećaj osifikacije apofize.Apofizitisi se mogu javiti na velikom broju kostiju u organizmu. Najčešće apofizitisi se javljaju u području golenjačne kvrge (tibijalni tuberkul) i poznat je pod imenom Osgood Schletter (Ozgud Šlater), zatim na glavi butne kosti - Legg - Calve - Perthes (Leg Kalve Pertes), na petnoj kosti Sever-ovo oboljenje...

Danas se sve veliki broj djece i adolescenata uključje u sportske aktivnosti tako nije rijetkost da djeca i adolescenti provode na dan i po nekoliko sati na treningu. Opisani su slučajevi maratonaca šestogodinjaka i djece koja su u bazenu plivala do 20 kilometara na dan te malih gimnastičarki koje su trenirale i po 6 sati na dan (Pećina, Bojanić \& Hašpl, 2001). Sindromi prenaprezanja najčešće se javljaju u najmasovnijim sportovima fudbalu i košarci.

Rast i razvoj djece posebno u doba puberteta posebno je vulnerabilno razdoblje za povređivanje, odnosno za nastanak sindroma prenaprezanja. Nije rijetkost da u pubertetu dječaci i djevojčice izrastu 10 i više centimetara u godinu dana. Rast mišića i tetiva ne prati u potpunosti brzinu rasta kostiju, te se najveći pritisak javlja na hrskavici apofize koja je biomehanički najslabija.

Osgood Schlatterovo oboljenje ili apofizitis tibijalne kvrge kao jedna od najčešćih juvenilnih osteohondroza, odnosno apofizitisa najčešće se javlja kod košarkaša.

Kao i u drugim bolestima u medicini i kod sindroma prenaprezanja važna je prevencija. Međutim moramo znati da je otpornost dječijeg organzima na dugotrajna i ekstremna opterećenja manja nego kod odraslih odraslih osoba. Jedan od osnovnih preduslova prevencije sindroma prenaprezanja lokomotornog sistema kod djece i adolescenata sportista je bolja edukacija sportskih radnika, posebno trenera. Pogrešno je mišljenje da su djeca fleksibilnija od odraslih i da ne trebaju vježbe istezanja kao uvod u trening. Važna je i sekundarna prevencija. Treneri moraju biti edukovani o simptomima sindroma prenaprezanja i kod pojave poèetnih simptoma djecu i adolescente treba poslati ortopedu jer je na vrijeme preduzeto liječenje je jednostavnije i kraće. (Pećina, Bojanić \& Hašpl, 2001)

Ključne riječi: Osgood Schlater oboljenje, košarkaši, trening. 